\title{
RECENZJE
}

Klio. Czasopismo poświęcone dziejom Polski i powszechnym

PL ISSN 1643-8191, t. 32 (1)/2015, s. 199-244

\section{O kulturze i jej historycznym badaniu w klasycznej perspektywie ${ }^{*}$}

\section{On culture and its historical investigation from the classical perspective}

W e wstępie swojej pracy Maria Bogucka informuje, że zajmuje się w niej różnymi kategoriami (aspektami) i funkcjami kultury, rozpatrywanej jako czynnik tworzący historię społeczną wraz z jej mentalnymi implikacjami [s. 7]. W kolejnych trzynastu rozdziałach omawia: „społeczne normy zachowań i sposoby bycia”, „kulturę elitarną i kulturę ludową”, „twórczość artystyczną”, „język”, „teatralność kultury”, „kulturę karnawału”, „mit i stereotyp”, ,anatomię kultury patriarchalnej”, „terroryzm”, „problem kozła ofiarnego”, „przestrzeń i czas”, „kulturę życia i kulturę śmierci”, „wizje końca świata”. Arbitralnie, jak zaznacza, wybrane aspekty kultur omawia w perspektywie historycznej. Zmiany w ich charakterze, a także przekształcenia funkcji prezentuje, odwołując się do tradycyjnych podziałów na epoki historyczne, od starożytności, przez średniowiecze i no-

* M. Bogucka, Kategorie i funkcje spoteczne kultury $w$ perspektywie historycznej, Oficyna Naukowa, Warszawa 2013, ss. 271, ISBN 978-83-7737-060-5. 
wożytność, po współczesność. Kluczowe miejsce w tych analizach zajmuje kwestia kryzysu współczesnej kultury. Stanowi ona ramy dla ujęcia przez autorkę charakteru i funkcji poszczególnych aspektów kultury.

Przedstawiając, jak rozumie pojęcie kultury, Bogucka w klasyczny sposób zaczyna od etymologii słowa „kultura”, następnie koncentruje się na kwestii ograniczania jej znaczenia do tzw. kultury duchowej i przeciwstawienia jej cywilizacji. Omawiając ten spór, przywołuje rozumienie kultury przez Fernanda Braudela, dla którego cywilizacja jest tożsama z kulturą. W tak naszkicowanych ramach dyskusji o kulturze, które obejmują zagadnienia z rzadka podejmowane współcześnie, proponuje następującą definicję kultury: „kultura to zespół materialnych i niematerialnych wytworów człowieka - są to zarówno wykonane przez niego domy, odzież, sprzęty, ozdoby, jak i społecznie uznane sposoby bycia i zachowań, systemy wartości i wierzeń, struktury społeczne i polityczne, nauka i sztuka (w tym obok malarstwa, rzeźby, architektury, muzyki, teatru, rzemiosł artystycznych także literatura), systemy komunikacji społecznej (język, gest) i ich formy (od tabliczki i rysika, poprzez druk, do telefonu, radia i [...] komputera" [s. 15].

Podana przez autorkę definicja ma enumeratywny charakter, podobnie jak klasyczna definicja z 1871 roku Edwarda B. Taylora, w której wprawdzie mowa jest o kulturze jako złożonej całości, ale definiowana jest tak, jak gdyby była jedynie zbiorem elementów ${ }^{1}$. Definicja podana przez autorkę określa szerokie pole badań i, podobnie jak definicja Taylora, pozwala jedynie na klasyfikację zjawisk według określonych bloków tematycznych - aspektów. W antropologii kulturowej, na gruncie której została sformułowana, pozwoliło to na skonkretyzowanie oświeceniowego pojmowania dzikości. Dotychczasowa kategoria „obyczajów” została zróżnicowana na składniki wymienione w definicji Taylora. Zasadniczą słabością takiego definiowania kultury jest brak kluczowych informacji dotyczących czynników kulturowych odpowiedzialnych za jej zróżnicowanie. Jak wiado-

1 „Kultura, czyli cywilizacja w najszerszym znaczeniu etnograficznym, jest tą złożoną całością, która obejmuje wiedzę, wierzenia, sztukę, moralność, prawo, obyczaje i inne zdolności i przyzwyczajenia, zdobyte przez człowieka jako członka społeczeństwa”. Cyt. za: A. Kuper, Kultura. Model antropologiczny, przeł. I. Kołbon, Kraków 2005, s. 49. 
mo, w przypadku definicji Taylora była to ewolucja; to ona, a nie kultura tłumaczyła zróżnicowanie obyczajów, decydowała o różnicach międzykulturowych. W późniejszych propozycjach definicji kultury na gruncie antropologii kulturowej ta różnorodność wyjaśniana była przez kulturę i jej liczne konkurencyjne teoretyczne ujęcia. Badacze, formułując kolejne teorie kultury, dążyli do lepszego i pełniejszego oddania „istoty” zróżnicowania sposobów życia człowieka.

W definicji autorki brak elementu określającego istotę zróżnicowania kulturowego. Jeśli byłoby to zamierzone, to na podstawie zaprezentowanej przez autorkę definicji należałoby uznać, że według niej badanie kultury polega na zinwentaryzowaniu jej cech, a nie jej przeanalizowaniu. Jednak parę zdań z wprowadzenia, w którym, jak wspominałem, mowa jest o badaniu funkcji kultury, wskazuje, że autorka zakłada jednak jakieś kulturowe mechanizmy odpowiedzialne za różnorodność kulturową. Możemy spróbować je zrekonstruować na podstawie innych wypowiedzi autorki. Niestety doprowadza nas to jedynie do sformułowania bardzo ogólnego stwierdzenia, w zasadzie niewiele mówiącego. Wydaje się, że z racji podkreślania przez Bogucką pełnienia funkcji przez różne aspekty kultury, stanowi ona strukturę funkcjonalną. Tyle, że jest to tak ogólne, iż jako teoretyczne założenie nic nie znaczy.

Wyjście poza enumeratywną definicję kultury pomogłoby także zrozumieć, co autorka ma na myśli, gdy pisze, że „kultura to oliwa, bez której maszyneria społeczna nie może działać bez zakłóceń, jej tryby i trybiki przestają się gładko obracać" [s. 29]. Przypomnijmy, że we wstępie Bogucka zaznacza, że zajmuje się w swojej pracy rolą kultury jako czynnika tworzącego historię społeczną. Jasne sformułowanie tego, jak postrzega relację między kulturą a społeczeństwem, jest bardzo istotne. $\mathrm{Z}$ podanej definicji wynika, że „społecznie uznane sposoby bycia i zachowań”, „struktury społeczne” stanowią aspekt kultury. Podobnie jak w definicji Taylora mamy tu do czynienia z rozumieniem kultury, w której obok aspektów ideacyjnych znajdują się także społeczne. Tymczasem z powyżej przytoczonej wypowiedzi wynikałoby coś przeciwnego, że autorka zawęża swoje rozumienie kultury i system społeczny umieszcza na zewnątrz kultury. Trudności w zrozumieniu tego, jak ostatecznie widzi ona relację między kulturą a społeczeństwem, 
nie da się także przezwyciężyć przez lekturę przedstawianych przez autorkę omówień konkretnych aspektów kultury.

Podobnie niedoprecyzowanie odnajdujemy w innych ważnych teoretycznych kwestiach. Czytelnik chcący zrekonstruować perspektywę badawczą autorki zmuszony jest do próby poszlakowej rekonstrukcji jej poglądów.

Autorka rozróżnia kulturę i cywilizację, które „wzajemnie oddziałują na siebie i współokreślają swój poziom i cechy charakterystyczne, odmienne w różnych regionach geograficznych i w różnych epokach” [s. 15]. Rozróżnienia dokonuje w specyficzny sposób, nie ma tu bowiem klasycznego oddzielenia tego, co duchowe, od tego, co materialne. W podanej definicji znalazły się zarówno wytwory rąk ludzkich, jak i sposoby życia, o których autorka wspomina, prezentując dyskusję wokół tego zagadnienia. Brak w definicji jedynie sposobów wytwarzania i technik produkcji [s. 11]. Można zatem przypuszczać, m.in. na podstawie esejów zawartych w książce, że one konstytuują cywilizację, która ma nieokreślony bliżej przez autorkę wpływ na kulturę. Nie wiemy też, jaki wpływ ma na nią kultura.

Powyżej poruszone problemy są istotne nie tylko z powodów teoretycznych. Gdybyśmy byli zaopatrzeni w merytoryczne wskazówki, które określają charakter podejścia autorki do zjawisk objętych pojęciem kultury, łatwiej czytałoby się nam kolejne rozdziały omawiające jej poszczególne aspekty i ich funkcje.

W swoim rozumieniu kultury autorka podkreśla „kontekst czasu i przestrzeni” dla powstania charakterystycznego oblicza kultur. Wskazuje na odmienność kulturową manifestującą się w postaci kulturowego zróżnicowania w różnych regionach geograficznych i w różnych epokach. Jak zauważa, „istnieje ogromna wielość czasowa i geograficzno-polityczna kultur (a także cywilizacji). Nic bardziej nie potwierdza istnienia i nie ogranicza niż kultura” [s. 15]. W ten sposób niewątpliwie autorka wychodzi poza definicję Taylora, w której jest mowa o kulturze jedynie w znaczeniu atrybutywnym. Mamy tu rozumienie kultury w znaczeniu dystrybutywnym, jako wyodrębnianej całości. Choć jak już wspomniałem, nie wiemy nic na temat charakteru owej całości, tego, co odpowiada za kulturowe zróżnicowanie.

Rozumienie kultury jako partykularnej, kontekstowej i systemowej całości zaproponowała kolejna generacja antropologów kultury, wprowadzając różne teorie kultury. Takie antropologiczne rozumienie kultury mia- 
ło swoje konsekwencje w badaniach. Dla ewolucjonistów jedynym ważnym przedmiotem badań były typy schematów rozwojowych kultury i jej poszczególnych dziedzin. Teraz istotne stały się różnice między poszczególnymi społecznościami i wchodzącymi w ich skład grupami i jednostkami. Co nie mniej ważne, wiąże się z tym porzucenie wartościującego rozumienia kultury. To, co kulturowe, jest jednocześnie kulturalne i odwrotnie - to, co kulturalne, jest jednocześnie kulturowe. Kultura nie jest pojęciem wartościującym, ale deskryptywnym, dotyczącym konkretnej grupy społecznej²

Bogucka nie posługuje się konsekwentnie pojęciem kultury w trybie deskryptywnym. Przykładowo, omawiając problem „społecznych norm zachowań i sposobów bycia”, pisze, że kultura średniowiecza to „stulecia barbarzyństwa i prymitywizmu, zwane ciemnymi wiekami, mrocznym średniowieczem” [s. 17], „W morzu prostactwa i barbarzyństwa specjalne wysepki kultury stanowity klasztory i dwory” [s. 18], „Człowiek średniowiecza to człowiek prosty na wszelkich szczeblach hierarchii społecznej" [s. 19]. Podsumowując swoje rozważania i odnosząc się do współczesności, autorka stawia pytanie "Jakie w tym nowym, wymykającym się dawnym normom

${ }^{2}$ Sygnalizując jedynie dyskusję i zmiany, jakie w końcu XX w. zaszły w rozumieniu kultury, należy zauważyć, że krytyka jej holistycznego rozumienia skłoniła niektórych badaczy do porzucenia pojęcia kultury. Mniej radykalni w swoich poglądach dokonali jego redefinicji. Badacze, którzy nie mają zamiaru „wylać dziecka z kąpielą”, odrzucają jedynie homogeniczne jej rozumienie i wskazują na nowe jej granice geograficzne. Jak sadzę, patrząc na dyskusję wokół pojęcia kultury z perspektywy historii antropologii, jesteśmy dziś świadkami nie tyle odrzucenia pojmowania kultury jako całości, ale obecnego w niej od zawsze poszukiwania nowego jej ujęcia. W praktyce badawczej zmiana ujawnia się w przeniesieniu ciężkości zainteresowań z trwałości i całościowości kulturowych wzorów na zmienność i wewnętrzne ich zróżnicowanie. Zob.: W. J. Burszta, Świat jako więzienie kultury. Pomyślenia, Warszawa 2008; idem, Teoria kultury, czyli „dtużej klasztora niż przeora", [w:] Kultura jako przedmiot badań. Studia filozoficzno-kulturoznawcze, red. B. Kotowa, J. Sójka, K. Zamiar, Poznań 2001, s. 157-169; A. Kuper, op. cit. Bardzo interesująca dyskusja, wywołana artykułem D. Czai, poddającego krytyce pojęcie „kultury” i proponującego zastąpienie go kategorią „życia”, odbyła się na łamach „Kontekstów”. Zob.: D. Czaja, Życie czyli nieprzejrzystość. Poza antropologie - kultury, „Konteksty. Polska Sztuka Ludowa. Antropologia kultury - Etnografia - Sztuka” 2002, nr 3-4, s. 6-22; W. Michera, Kultura, empatia i techniki skrawania, ibidem, s. 23-25; W. Szpilka, „Żyj i daj życ", ibidem, s. 26; Cz. Robotycki, Hermeneutyka i Życie na marginesie rozważań Dariusza Czai, ibidem, s. 27-28. 
społeczeństwie funkcje spełnia kultura?”. Odpowiada: „na pierwszy rzut oka wydaje się zjawiskiem zanikającym, marginalnym, związanym jedynie z grupkami intelektualistów. Miejsce kultury »wysokiej«, "uczonej« zajęła popkultura stanowiąca żałosne popłuczyny po dawnej kulturze ludowej, masowej. Dziś nie tworzy już [...] żadnych wartości” [s. 29].

Autorka dokonuje zatem wyodrębnienia kultury jako pewnej partykularnej i jakiejś bliżej nieokreślonej systemowej całości, ale już nie kontekstowej. To, co kulturowe i kulturalne, uzależnione jest każdorazowo od kontekstu społeczno-kulturowego. Tymczasem u autorki „kulturalnośc” i bycie kulturowym wyznacza norma w postaci kultury „wysokiej”, „uczonej”, która - jak wyżej zaznaczyłem - stanowi podstawę jej analiz.

Ostatecznie zatem, biorąc pod uwagę deklaracje autorki i praktykę analityczną, można stwierdzić, że w swoim rozumieniu kultury łączy jej rozumienie jako całościowego sposobu życia z jej rozumieniem występującym w angielskiej tradycji literacko-romantycznej, którą określiły rozważania nad stosunkiem między kulturą wysoką, kulturą masową i postępem materialnym. Dla jednego z kluczowych jej przedstawicieli Matthew Arnolda kultura to kultura wyższa, to, co najlepszego może osiągnąć gatunek ludzki w obszarze ducha. Kultura jako studium doskonałości „prowadzi [...] do wyobrażenia sobie prawdziwej ludzkiej perfekcji jako harmonijnej doskonałości umożliwiającej wszechstronny rozwój naszego człowieczeństwa; jest także ogólna doskonałością pobudzającą wszystkie warstwy naszego społeczeństwa"3. Tak rozumiana kultura jest według Arnolda remedium na aktualny stan niedowładu struktur społecznych ${ }^{4}$. W efekcie powiązania tych dwóch sposobów rozumienia kultury, pozostających w sprzeczności, dla autorki kultura nie utożsamia się jedynie z tzw. kulturą humanistyczną, ale obejmuje szerokie spektrum aktywności ludzkiej, co wynika z jej sposobu rozumienia jako całościowego sposobu życia. Jednocześnie o tym, co jest kulturalne i kulturowe, decyduje nie kontekst społeczno-kulturowy, jak to się dzieje w rozumieniu kultury jako sposobu życia, ale norma w postaci tzw. kultury wysokiej, która wyraża ideał kulturalnej doskonałości.

3 Cyt. za: Ch. Jenks, Kultura, przeł. W. J. Burszta, Poznań 1999, s. 33.

${ }^{4}$ F. Inglis, Kultura, przeł. M. Stolarska, Warszawa 2007, s. 39. 
Jak takie rozumienie kultury przekłada się na obraz jej kategorii i funkcji na przestrzeni dziejów, zaprezentowany w poszczególnych rozdziałach omawianej pracy? Wspólnym mianownikiem wszystkich rozdziałów pracy jest pewien ukryty przez autorkę ideał kultury, który stoi u podstaw niekontrolowanej imputacji kulturowej, zamknięty w pojęciu kultury „wysokiej”, „uczonej” i jej przeciwstawieniu kulturze „ludowej”, „popularnej”, „masowej”. Kultura „wysoka” pozostaje w „interakcyjnej koegzystencji” z kulturą ludową. Jej dominacja oznacza zawsze, że wszystkie z wyróżnionych przez autorkę aspektów kultury i ich funkcje znajdują się na najwyższym poziomie. Mamy obraz rozwoju kultury, który waloryzowany jest ze względu na zajmowane w niej miejsce przez kulturę „wysoką”. Według autorki w dotychczasowym rozwoju kultury nigdy jeszcze kultura „wysoka” nie miała tak niewielkiego znaczenia jak w XX wieku, co zagraża dalszemu funkcjonowaniu kultury w ogóle.

Przez długie stulecia, aż do wieku XX - pisze autorka - w tej interakcyjnej koegzystencji dominowała kultura wysoka, tworząca wartości i wzorce zachowań obserwowane i naśladowane mniej lub bardziej udolnie przez lud. W łonie kultury ludowej, popularnej również zresztą powstawały pewne wartości i wzorce, które, przyswajane przez członków elit, oddziaływały na kulturę wysoką. Popkultura $[\ldots]$ tych zdolności już nie ma [s. 31].

Dziś dawne ludowe masy zastąpił tłum bliższy dawnemu motłochowi, jego zwycięstwo

przyspieszyło i przypieczętowało degradację moralną i intelektualną elit: kultura „wysoka” znalazła się po raz pierwszy na marginesie życia społecznego, bezbronna wobec nowej rzeczywistości [s. 45].

Przeprowadzone przez autorkę w kolejnych rozdziałach ksiązi analizy wybranych aspektów kultury mają udowodnić, że żyjemy w czasie zmierzchu kultury i świata, a czterech jeźdźców apokalipsy zastępuje jeden - popkultura, tak jak oni niosąca zniszczenie. Wraz z marginalizowaniem kul-

${ }^{5} \mathrm{Na}$ temat stronniczości myślenia historycznego i zagadnienia imputacji kulturowej w historii zob.: W. Wrzosek, O myśleniu historycznym, Bydgoszcz 2009. 
tury wysokiej nastąpiła degeneracja funkcji kultury, co jest jednoznaczne z jej zanikiem. Popkultura nie jest kulturą, a efekty tego są destrukcyjne dla „maszynerii społecznej”, która nie może gładko pracować. Zagłada ludzkości to tylko kwestia czasu.

Nieco więcej miejsca poświęćmy temu, jak Bogucka analizuje sztukę jako aspekt kultury. W rozdziale Twórczość artystyczna $w$ kulturze różnych epok historycznych autorka podkreśla, że funkcje sztuki były różnicowane na przestrzeni dziejów. W antyku sztuka jej zdaniem miała dostarczać pozytywnych wzruszeń. Odbiorca miał delektować się pięknem i doskonałością przedstawianych form. W średniowieczu delectare zostało zastąpione hasłem docere - pouczać. Było to związane ze ścisłym związkiem sztuki tej epoki z religią, z powierzeniem sztuce zadań dydaktyczno-ewangelizujących. W renesansie i baroku wraz z modą na antyk odżywa hasło delectare. Cały czas obok tych dwu podstawowych funkcji sztuki istniała, z mniejszym lub większym natężeniem, funkcja budzenia obok podziwu także silnych emocji negatywnych - strachu, wstrętu, obrzydzenia [s. 54]. Ta ostatnia funkcja, silnie związana z dydaktyką religijną, w XIX wieku oderwała się od niej i stała się celem samym w sobie [s. 54]. „Na całym świecie - pisze autorka - zaistniała [...] moda na brzydotę, prymitywizm, tendencja do wzbudzenia obrzydzenia i przestrachu zamiast oczarowania i podziwu. Jest to rezultat [...] także, a może nawet przede wszystkim, efekt zwycięstwa kultury masowej, popularnej, która od wieków opierała się na krzykliwym wulgaryzmie, nad kulturą elitarną, wymagającą wykształcenia i refleksji”" [s. 58]. W zakończeniu tego rozdziału na temat śmierci sztuki czytamy:

Czy społeczeństwo, które akceptuje taką sztukę, jest społeczeństwem zdrowym psychicznie? Zwycięstwo popkultury i pop-artu, wszechwładza mass mediów, ogłupiająca widzów serwowaną im prymitywną papką, świadczą o nieznanym nigdy przedtem zaniku walorów estetycznych i moralnych sztuki. Triumf brzydoty i beztalencia kształtuje nową epokę [...] [s. 66].

W rozdziale tym, podobnie jak i w pozostałych, kwestia poznania kultur stoi na drugim planie. Autorka koncentruje się przede wszystkim na moralizowaniu, opartym na jej rygorystycznym wyobrażeniu o tym, jaka ma być „prawdziwa” kultura. Opozycja kultury wysokiej i popularnej bu- 
dowana jest przez autorkę na argumentach sformułowanych jeszcze w czasach romantyzmu, które $\mathrm{w}$ dyskursie o kryzysie są modyfikowane i rozszerzane, bez wiedzy nawet o ich rodowodzie. $Z$ podanych przez Jerzego Jedlickiego takich argumentów odnajdujemy u Boguckiej, poza estetycznym, który w klasycznym kształcie brzmi „cywilizacja zabija wyobrá́nię, sztukę, poezję, a nawet samo poczucie piękna”, także argumenty: moralny, polityczny, socjologiczny, narodowo-kulturalny ${ }^{6}$.

Autorka dokonuje krytyki kultury popularnej zarówno z pozycji egalitarystycznych charakterystycznych dla konserwatystów, jak i marksistowskich. Jak zauważa Jenks, konserwatywne thumaczenie ubóstwa kultury masowej wynika z poglądu „o nieadekwatności, doczesności i przyziemności statusu zbiorowego smaku publiczności i zdolności odbioru"', a interpretacja marksistowska $\mathrm{z}$,pośrednictwa rynku i erozji spontanicznej kultury ludowej w technicznej i komercyjnej kulturze popularnej narzuconej niezależnie od woli samych mas", która zabija wszelki krytycyzm. Podobnie jest u autorki, dla której, jak już zauważyłem, kulturę wykształconej mniejszości pracującej nad projektem kultury wspólnej dla wszystkich wypiera popkultura wytworzona przez rynek, zabijająca wszelki krytycyzm. Pisze ona m.in. „Na pierwszy rzut oka [kultura wysoka - przyp. W.P.] wydaje się

${ }^{6}$ „Argument moralny: iż to jest cywilizacja bezwzględnej rywalizacji, zachłanności, wojny społecznej, wyzwala ona w ludziach ich najniższe popędy: żądze posiadania, używania, panowania, podboju, nie pozostawia miejsca na cnoty wielkoduszności, wierności, dumy, współczucia [...]. Argument personalistyczny: iż ta cywilizacja, oparta na podziale pracy i etyce utylitarnej, rozczłonkowuje osobę ludzką na poszczególne funkcje, czyni z człowieka maszynę, a ze społeczeństwa targowisko; kultura staje się światem sztuczności, pozorów, hipokryzji, czyli opinii-luster, wśród których jednostka traci poczucie tożsamości, wolności wewnętrznej, godności moralnego podmiotu. Argument socjologiczny: iż ta cywilizacja rozkłada wspólnoty rodzinne, gminne, stan - czyniąc z ludzi samotne atomy, mogące wiązać się z innymi tylko wspólnotą interesu; wraz z tym społeczeństwo staje się 'rozbitą całością', 'zsypką cząstek', 'kupką piasku' [...]. Argument narodowo-kulturalny: iż cywilizacja miejska i przemysłowa jest wszędzie jednaka, a zatem w ekspansji swej zatraca indywidualne charaktery kultur narodowych czy etnicznych, niweluje w ogóle różnobarwność ludzkiego świata”. J. Jedlicki, Trzy wieki desperacji. Rodowód idei kryzysu cywilizacji europejskiej, „Znak” 1996, t. 1(488), s. 15-16.

7 Ch. Jenks, op. cit, , s. 144.

${ }^{8}$ Ibidem. 
zjawiskiem zanikającym, marginalnym, związanym jedynie z grupkami intelektualistów. Miejsce kultury 'wysokiej' zajęła popkultura stanowiąca żałosne popłuczyny po dawnej kulturze ludowej, masowej. Dziś [...] jest tylko zabawą ludową, narkotykiem oszałamiającym Massy, silnie związanym z rozwojem techniki i mass mediów” [s. 28]. Przytaczając niektóre z opinii badaczy na temat kultury popularnej, ograniczając się przy tym jedynie do „pesymistów kulturowych”, zauważa: „A więc kultura masowa w XX w. to nie spontaniczna twórczość mass ludowych [...] lecz konsumeryzm, bierność i spłycenie kryteriów moralnych, rozwój permisywizmu” [s. 41]9.

Praca Boguckiej - wybitnej znawczyni kultury - jest książką napisaną przez intelektualistkę, która zaniepokojona jest w swoim mniemaniu złym kierunkiem rozwoju kultury. W kolejnych, pełnych erudycji rozdziałach prezentacja zmian $\mathrm{w}$ funkcjonowaniu różnych aspektów kultury podporządkowana jest przekonaniu o kryzysie współczesnej kultury. Niekontrolowana w żaden sposób przez autorkę imputacja kulturowa powoduje, że jej analizy niewiele mówią nam o omawianych kulturach, za to wiele mogą powiedzieć o niej samej jako badaczce kultury i zapewne szerzej - o historiografii polskiej. Trudno się nie zgodzić z Jedlickim, że „za jedyną sensowną definicję kryzysu cywilizacji uznać wypada postulat, że to jest kryzysem, co się komu widzi, zaś dzieje owych widzeń i dyskursów stanowią ogromnie rozległy i dla historyka frapujący przedmiot badań [...]"10. Co ciekawe, ostatni z rozdziałów książki Boguckiej Czas apokalipsy. Wizje końca świata jako przejaw mentalnej reakcji na wydarzenia epoki przetomu poświęciła ona „niepokojom i frustracjom mentalnym”, które towarzyszą epokom przełomu, „niosącym radykalne zmiany w egzystencji jednostek [podkreśl. W.P.] i całych społeczeństw” [s. 238]. Oczywiście warunki do odżycia w XX i początkach XXI wieku, jak pisze autorka, „ludowej magii i przesądów, kwitnących w dawnych stuleciach” pojawiły się wraz ze „Zwycięstwem popkultury nad kulturą elitarną, wysoką” [s. 269]. Pytanie o charakterze retorycznym brzmi: na ile książka Boguckiej jest przejawem

9 Poglądy „pesymistów kulturowych” oraz „optymistów kulturowych” na temat kultury popularnej omawia J. Barański, Etnologia i okolice. Eseje antyperyferyjne, Kraków 2010, s. 143-169.

${ }^{10}$ J. Jedlicki, op. cit., s. 5. 
„mentalnej reakcji na wydarzenia epoki przełomu”? Oczywiście nie w ramach popkultury, ale kultury „wysokiej”, pamiętając o podziałach autorki.

Rozczarowaniem dla czytelnika omawianej książki jest przede wszystkim niewykorzystanie przez autorkę potencjału historycznej analizy kultury. Formalnie otrzymaliśmy obraz zmieniającej się kultury, kolejne epoki historyczne to inne kultury, ale ich kulturowa treść „pochodzi” z kulturowego kontekstu autorki. Kultura w analizach Boguckiej to nie konwencja związana z wyborem jakiegoś sposobu życia, ale fundamentalne przekonania na jego temat. Paradoksalnie autorka, wybitna historyczka, zapomniała, że „kultura zmienną jest”. A któż obok antropologów powinien o tym wiedzieć lepiej niż historyk? Fundamenty poznania historycznego predysponują historyka, by tak jak antropolog w swojej pracy był „koneserem zróżnicowania”. W sposób przejrzysty pisze o tym Wojciech Wrzosek:

Zestawiam strategie poznania historycznego z antropologicznym i twierdzę, że podobnie jak antropolog realizuje swe poznanie, które da się opisać następująco: kultura bada kulturę, to samo można orzec o historyku. Historyk bada przeszłość, która ze względu na niekiedy znaczne oddalenie w czasie jawi się mu niejednokrotnie drastycznie odmienna (zaskakująco inna) od kultury, którą sam reprezentuje. Klasyczna antropologia podobnie: zgłębia egzotyczne (dzisiaj już nie tylko takie) przejawy kultury jemu współczesnej, często oddalonej w przestrzeni od jego kultury rodzimej. Obaj tropią podobieństwa i różnice między kulturą badającą a badaną, chcą je opisać, zrozumieć i interpretować. Godzą się bowiem z prostym spostrzeżeniem, że kultura jest czasoprzestrzennie zróżnicowana. Dla historyka różnice funduje nade wszystko czas, dla antropologa kulturowego przede wszystkim przestrzen ${ }^{11}$.

Historyk, podobnie jak antropolog, badając kulturowe zróżnicowanie w czasie powinien kierować się ideałami, o których tak pisze Wojciech J. Burszta, określając je jako rudymenty antropologicznej postawy wobec świata i innych ludzi:

11 W. Wrzosek, op. cit., s. 18. Zob.: C. Geertz, Pożytki z różnorodności, [w:] idem, Zastane światto. Antropologiczne refleksje na tematy filozoficzne, przeł. Z. Pucek, Kraków 2003, s. 107. 
są to [...] ideały nakazujące doceniać i próbować zrozumieć uderzającą Inność każdego człowieka, każdego społeczeństwa i każdego elementu społecznego porządku wartości. [...] najpierw opisuj, staraj się zrozumieć, przekaż to zrozumienie innym, nigdy nie oceniaj pochopnie i unikaj etnocentryzmu. W Innym dostrzegaj Siebie ${ }^{12}$.

Wojciech Piasek

12 W. J. Burszta, Antropologia kultury. Tematy, teorie, interpretacje, Poznań 1998, s. 179 . 